\title{
Reconstruction Legal Culture of Madurese Based on Pancasila Values as Criminal Policy in Tackling Carol
}

\author{
WP Djatmiko, ${ }^{1}$ Suteki $^{2}$, Nyoman Serikat Putra Jaya ${ }^{3}$ \\ \{email: djatmiko.ldwd@gmail.com ${ }^{1}$,email: arjuna_teki@yahoo.com ${ }^{2}$, \\ email: putrajaya1948@yahoo.co.id ${ }^{3}$ \}
}

\author{
Diponegoro University, Jl.Prof. H. Soedarto, S.H. Tembalang, Tembalang, Kota Semarang, Jawa \\ Tengah, 50275, Indonesia ${ }^{1}$ \\ Diponegoro University, Jl.Prof. H. Soedarto, S.H. Tembalang, Tembalang, Kota Semarang, Jawa \\ Tengah, 50275, Indonesia ${ }^{2}$ \\ Diponegoro University, Jl.Prof. H. Soedarto, S.H. Tembalang, Tembalang, Kota Semarang, Jawa \\ Tengah, 50275, Indonesia ${ }^{3}$
}

\begin{abstract}
This study attempts to uncover carok, a tradition used as a solution to overcome problems related to the humiliation of a man's honor in the Madurese. This homogenous society believes that dying would be better than living enduring shame. It seems that carokbecomes a socio-cultural fate for the Madurese, which is a means to express their ethnological destiny. Despite several efforts to prevent carok, such tradition keeps existing. It means that the affirmative legal instruments fail to provide a solution. Therefore, reconstructing the legal culture of the Madurese based on Pancasila's values to overcome the problem is proposed to be an alternative. This research has three objectives that are to find out:(1) Why the Madurese choose carok as a final solution (2) What the effects of using carok are (3) How to reconstruct the Madurese legal culture based on Pancasila's values to avoid carok. The study concludes that (1) Carok is chosen because it is a social norm gaining social supports; (2) The effects of using carok are that there are participants who (i) agree, (ii) disagree (iii) agree on carok in the case of humiliation of the wife's honor only (iv) there is a hope to have powerful generations and there are increasing roles of the local elites (3) The construction of the Madurese legal culture can be achieved by (i) emphasizing the roles of parents and the local elites (ii) influencing people's perspective that vigilante justice is harmful (iii) building legal awareness and operating a type of the informal justice systems (IJS) named Lembaga MusyawarahAdat (LMA) to overcome carok and other social problems.
\end{abstract}

\section{Introduction}

The Madurese is an Indonesian tribe living mostly in Madura Island. The distinctive anthropological features of the people are that they are open, expressive, spontaneous, religious, and polite. Furthermore, almost all the Madurese are Muslim. However, despite being devoted Moslem, they have yet to perform the Islamic moral values (tolerance, forgiveness, and patience), mainly when they deal with social problems, such as harassment of one's honor, wife, religion, land and water disputes. One of the deeds that do not reflect the religious values is carok. Cookies an act of murder by using a sharp knife, commonly celurit, done by a man to another person who conducted an act of humiliation that results in shame. The main factors causing carok are pride and shame. Shame is a significant psychological burden for a man in the Madurese society. Shame is considered taboo, and it 
must be avoided. A man in this society must be dauntless to perform carok. People will look down on him by calling "lo lake" meaning "not a male person" if he is not brave enough to do so. They believe that death would be better than living enduring shame. Carokseems to be a socio-cultural fate for the Madurese, a means to express their ethnological destiny. Hong and Yuxuan describe word ethnological is refer to the human community generally considered to share common historical, linguistic, geographical, or cultural bonds and objectively distinguished from the "others." Examples include clans, tribes, tribal alliances, ancient empires, feudal kingdoms, and feudal empires [2].

Undoubtedly, carokis against the positive Indonesian law, human rights, religions, and Pancasila. According to the Indonesian Criminal Code (ICC), the action of conducting harassment of one's honor including harassment of woman is considered as a crime in which the doer is subjected to the article 281 to 287 of the ICC. Therefore, to overcome a humiliation on one's honor by carok is not in line with the positive law. Quite the contrary, the majority of the Madurese think that carok is not a prohibited action, and it is not a crime. Most people in this tribe believe that performing carok for the sake of guarding one's honor is likely equivalent to engaging in holy war (jihad) in Islam. They consider that across a custom that people have to do to defend and maintain their honors physically. In line with De Sousa Santos opinion that proposed custom, instead of being a primary source of law, will only rise to the "law" category "whenever it will be a determinant factor of social and economic progress and should be rejected if it is maladjusted to the political principles which guide the new type of society we endeavor to create" [3].

This phenomenon shows that state law seems useless in maintaining social peace and order in this homogenous society. In other words, the law as a means of social control is no longer able to count on the capacity of formal legislation anymore fully. It is considered to be a burden to solve tribal social conflicts, and it also influences the existing indigenous social values. Therefore, upon examining the above phenomenon, reconstructing Pancasilabased legal culture of the Madurese is crucial to handle carok. Silbey argued that legal culture is analytical to identify the meanings of law that circulate in social relations [1].

The research questions of this study are: (1) Why do the Madurese choose carok as a final solution to solve conflicts in dealing with harassment of one's honor? (2) What are the effects of using carok as a solution? (3) How do we reconstruct the Madurese legal culture which is based on Pancasila's moral values to avoid carok?

\section{Methodology}

Some essential and relevant micro and macro theories have been employed as a theoretical approach to analyzing the research questions. The micro theories being used are Husserl's Phenomenology and Gadamer's Hermeneutics. These micro theories are exploited to obtain a comprehensive understanding of the phenomenon of carok. Meanwhile, the macro theories cover Friedman's Legal System, Durkheim's Social Solidarity, and Ancel's Criminal Policy Theories which are used to examine thoroughly all factors related to society, law, and order.

To answer the above research questions, we deployed the naturalistic qualitative research method, where the researchers themselves function as pivotal vital instruments. Conti \& O'Neill stated that applying qualitative approaches has tremendous benefits that aid the researcher in the process of doing research and generates a nuanced understanding of the complex and multi-layered operations of power [12]. 
The primary data are taken by conducting in-depth interviews to selected vital informants and direct observations, whereas the secondary data are obtained by internet browsing and reading relevant bibliographies. A non-doctrinal study focusing on the case of legal culture is used as the foundation. The study applies a socio-legal approach under Guba's constructivism paradigm. It means that the findings in this study are built by constructing all views and values given by both researchers and participants involved. This socio-legal research had been carried out for more than six months in 2016 in three villages: (a) Jaddih; (b) Parseh; and (c) Bilaporah at SocahSubdistrics, Bangkalan District, MaduraEast Java.

\section{Findings}

\subsection{Carok is a Social Norm Gaining Social Supports}

The study discovers that the Madurese regard a man's honor as the most valuable asset in life. For this reason, a man is willing to sacrifice his life to maintain his honor. Maintaining a man's honor is an influential culture, and it has been taught and transferred from generation to generation. Consequently, for those destroying a man's self-esteem and look down on his honor must be sentenced to death by carok. The tribe's way of behaving has influenced its men's behavior and their way of thinking. He is also influenced by which of the most dominant value of culture they hold. Their most valuable culture will be regarded as the most valuable asset in their life. Most participants say that the most valuable asset in their lives is the honor of wife, family, religion, and property, respectively. In line with Swidler argument that culture shapes action by supplying ultimate ends or values toward which action is directed, thus making values the central causal element of culture[4].

Performing carok as a payback to avenge humiliation has become a social norm. It can be said that carok is an action which is oriented toward values (wertrationalhandeln). Based on this argument carok is contemplated as an action which gets social legitimacy and social supports. A man performing carok is influenced by his social, cultural, and behavioral system. These systems have manifested as a traditional action.

All the participants say that conducting harassment of one's honor that results in shame will be categorized as an inequitable deed to others. Such inappropriate act makes a person and his family members feel ashamed, disappointed, and furious. The case of humiliation will draw more attention when it deals with the honor of a wife. The majority of the participants also say that there is an unwritten law (gewoonterecht) where those who allegedly conducted harassment to the honor of one's wife will get no sentence but death. The participants state that murdering the doer who is claimed to harass the honor of one's wife is perceived as social and substantive justice.

\subsection{The Consequences of Using Carok as a Final Solution and the Hopes to Have a Powerful Generation}

This study reveals that: (1) There are participants who completely disagree on carok being used as a solution since carok is harmful to modern civilization. It results in unnecessary deaths and causes killing retaliation habits. They argue that social problems should not be solved by performing carok. Most of them say that the use of state law is imperative. They also admit that the state law is not yet providing substantive justice in these humiliation cases, but as a good citizen, they feel that people must obey the positive Indonesian law. Participants belong to this group are police, educated persons, Islamic religious leaders, and university students. (2) Some participants fully agree on carok since doing the assassination is the only way to achieve substantive justice. They think that carok is the 
only way to achieve real justice. They also argue that carok is a social norm that had been practiced by their ancestors for an extended period before. According to their beliefs, killing the doer is the manifestation of substantive justice, and it is just compulsory to do so. Participants who share these opinions are local hoodlums (blaterkene'), traditional peasants, fishers, labors, public transport drivers, and traditional traders. (3) Some participants will agree on carok only if the case is related to the wife's honor. This group of people thinks that the death sentence is the only solution to the case of harassment of one's wife only and not for anything else. According to them, for the cases of land, wealth, religion, and water disputes, solving them through a cultural mediation is advisable. Participants who share these opinions are successful traders, farmers, and government officials. (4) Some participants also claim that to have power generation is expected. According to them, the ideal upcoming generations should possess bravery, adequacy in fighting techniques, and extraordinary supernatural powers as the best guard of the family (orengangko).

Such hopes in the Madurese families are a cultural fact that having a power generation is an ideal of its people. They are well depicted in the old traditional song sung by the Madurese parents for their beloved boys. The rhyme is: "Gengantarnyak, jhukoklanggung, mon bengalkannak, mon takokdor-ondur," which means "Amaranth vegetables, tuna fish. Who has bravery, come hire to fight. If you do not have it, go away far from me." The lyric implies the Madurese's hopes that their descendants could become the most potent eminent guard to protect their prominent families and to win carok if the fate forces him to do so.

Moreover, there are three crucial actors in the socio-culture relationship in Madurese society. They are kiai (Islamic religious leader), later (hoodlum) and klebun(the village head officer). They are social, political, and cultural brokers for their society, and all of them belong to the village's elites. Compared to later and klebun, the existence of Kiai plays a more significant role in the area of carok. According to some participants, instead of coming for advice, people come to kiai for performing Islamic mystical rituals, magic spells, amulets and for asking for extraordinary powers, especially when they want to perform carok. They also say that supernatural powers drawn from mystical Islam are essential attributes to win carok.

The two other important actors in carok issues are klebun and later. Klebun or the village head belongs to the local elites. Klebun has official responsibilities in managing governmental issues in a village. The local people consider klebun as both social and political leader. In the field of carok his role is vital since he knows his people well. When there are criminal matters, people let klebun know them first. With his political power, klebun together with the other local elites (kiyai and later) and the village police officer (Babinkamtibmas) can manage and prevent carok by conducting traditional mediation institution/ LMA functioning as the informal justice system/IJS or inheemscherechstpraakto handle social and particular criminal problems. Chia et al. stated that mediation is a way to recognize as reputable members of the community, they are expected to help the community uphold justice, maintain harmony and good relations, and reinforce the community's standards of behavior [6].

The strategic role of bilateral also significant in the area of carok. Blateris are usually responsible for the peace and social order in the village. A well-known blatermight play a significant role in peace and social order of the village where he lives in and other villages around his domicile. Blatter usually knows well about carok since he used to be the winner in the battle of carok. Therefore, later should be included in the LMA because of his knowledge about issues concerning carok. Kiai, together with the other two local elites and 
the Babinkamtibmas actually can manage to solve the common social problems through the LMA.

3.3 The Construction of the Madurese Legal Culture Based on the Pancasila's values to Prevent Carok

The study finds that three preventive systems are prominent in minimizing carokin the Madurese. The first preventive system is parents' involvement to tackle carok. The Madurese regard parents as the most important entities to be given the highest respect in life. Behaving politely toward parents and obeying their guides and instructions are strong cultural values for this tribe. A parent is allowed to do anything to their descendants. With such authority held by parents, they will be able to stop their sons not to perform carok.

Aside from parents, a big family is also another entity to consider. A big family in this study covers all family members (close and peripheral kin) or a big family from both mother's and father's ancestors as well as their descendants. In the case of carok, a big family gives significant contributions in term of psychological and financial supports to the man who is going to perform carok. Sometimes, a big family can be a puzzling factor when reconciliation and mediation are initiated. The idea of retaliation in care often comes from a big family. Prominent families of both sides must be involved in the mediation and reconciliation processes to make a permanent and steady agreement to avoid carok.

The second preventive system is the involvement of Kiai. Undoubtedly, the legitimacy of kiai's social and cultural positions in the Madurese society can be a pivotal capital to make people obey the positive law. Local people wholeheartedly follow instructions and guides given by Kiai. Being at the highest social status, Kiai certainly has an ample role, especially in the issues of religious law relating to carokmatters. He is the guardian of moral authority because people rely on his guidance and insight on almost every matter of life. People always come to him for help and advice. Therefore, Kiai is the essential agent to change the Madurese men's perspective about carok.

The third preventive system is the involvement of umaro' (government officials such as klebun and Babibkamtibmas) in tackling carok. Generally speaking, the Madurese show high mutual respect to government officials. This socio-cultural reality can be used as a pivotal capital to improve community safety relating to crime prevention, especially for the case of carok. Local government officials, together with both kiaiand blatercan work together to create targeted action plans and a framework to tackle community safety, focusing on the case of carok prevention.

The above preventive systems are identical to the socio-cultural concept of the Madurese: the absolute fidelity to Bapa' babhu' ghururato, which means giving absolute loyalty to father/mother, Kiai, and government. These three entities are the leading agents in changing the legal culture of the Madurese, especially in the case of harassment of a man's honor, wife, religion, land, and water disputes that result in shame. These main agents should consider that crime and safety problems, particularly carok, as a quality-oflife issue. They must work together to identify and remove the sources of crime which possibly lead to carok. The legitimacy of Kia's authority and credibility can be a meaningful capital to manage this partnership and build legal awareness in society.

Developing and sustaining partnership strategy among parents and the local elites must be first accomplished. This strategy covers campaigning that vigilante justice is harmful to society. Then it must be followed by a community partnership. This strategy belongs to other legal system or traditional and straightforward system. Vigilante justice (eigenrichting) happens when people have zero trusts in the existing legal system. Everybody will be able to set himself as a purveyor of justice and impose his own rule 
through vigilante justice. However, this does not provide his action a legal legitimacy. Most participants revealed that they do not trust cops and courts to obtain a substantive justice that they want to get.

Any society which condones vigilantes might give thugs an easy alibi. The risk and reward balance will not be favorable any longer for society as a whole. Moreover, vigilante justice is against the second principle of Pancasila: 'equitable and civilized humanity.' Vigilante justice is also against any religious doctrines and human rights. Every religion in the globe prohibits the practice of taking other's life. Islam, for instance, never tolerates killing someone without proper reason. This doctrine is underlined in the holy Quran, Surah al-Israa, article 33. Besides, according to the second principle of Pancasila, carok causing somebody's death is considered as an uncivilized deed which harms human rights.

The practice of carokis identical to the act of ripping the natural right of a person, i.e., the right to live. This right is given directly by God Almighty. In order to get foreign direct investments to Madura Island, the government has to answer global challenges. Globally, countries in the world must guarantee and protect the right to live of their citizens. This obligation is attached in the Universal Declaration on Human Rights (DUHAM) and the International Covenant for Civil and Political Rights.

DUHAM article 3 states that everyone owns individual rights of his own life, freedom, and safety. Therefore, the right to live is a human right it has to be guaranteed and protected by state, including Indonesia. Such human right is stated in the International Covenant for Civil and Political Rights. Covenant article 6 states that the rights to live cannot be taken arbitrarily. Hence, it is evident that carok as a legal culture of the Madurese is against Pancasila, religions, positive Indonesian law, and international human rights. The practice of carok must be eliminated, or the legal culture of the Madurese must be reconstructed. The changes in the Maduranese culture will eventually be regarded as a social change.

Legal awareness is an awareness which is present in every individual to the given or expected laws. Developing legal awareness in Madurese means developing conscience existing within every Madurese as a member of society by empowering the positive Indonesian law as a method to overcome problems that potentially trigger carok. Building legal awareness of a society should be firstly initiated by developing legal awareness for everyone since self-awareness is an awareness of doing or not doing a particular behavior because of justice demands. In line with Heinen and Shrivastava research, which stated that a higher level of awareness on regulations could be associated with negative conservation attitudes [5].

The interaction of people gradually will form a feeling of solidarity about fair and unfair, things to do and not to do in an individual situation as it is necessary to realize order and law in the society. By doing this, it will result in people legal awareness. Legal awareness will lead to the obedience on law, that is the use of positive law to handle problems that may arise from harassment of a man's honor that results in shame. Legal obedience is categorized as physical obedience since the state forces its citizens to obey. Blass stated it as simple-command authority; namely, whose power to command and exact obedience is based on legal or quasi-legal considerations, not because of any particular expertise regarding the task at hand [7].

Therefore, the law will effectively operate since the Madurese obey the positive law.

Because the Madurese belongs to a patron-client type of society, the legal culture of the patrons (local elites) plays a significant role to adhere the society (clients). They depict the portrayals in their society. Cooperation, synergies, and commitments of local elites are essential to avoid carok. 
Engaging in deliberationhabits of the Madurese to solve social problems should campaign where it can be achieved through legal awareness illuminations and Islamic religious teachings. This tribal habit reflects the implementation of the fourth moral principle of Pancasila, and it belongs to a non-penal criminal policy approach.

The non-penal policy covers several methods of coping with vast areas in social policy and national development matters. Some of those methods can be achieved through social activities such as neighborhood youth association, religious teachings, etc. For the case of the Madurese, the possible applicable non-penal areas could be giving legal awareness extension through routine religion lessons like Yasinan and Friday religious speech on mosques, charity, social education to develop social responsibility of the society, and improving social welfare, etc. In line with Beckett\& Western opinion that social policy becomes more punitive like penal policy [10].

Developing legal awareness by encouraging the use of positive Indonesian law as a method to handle problems behind carok is a must. Legal awareness will lead to obedience to the law. To build legal awareness of the Madurese can only be achieved by implementing Pancasila's moral values in their daily lives. In order to reach this objective, everyone in this tribe must completely understand, mentally digest, and fully comprehend Pancasila's moral values. When Pancasila moral values have influenced their actions and behaviors in their interaction with others, it can be said that the Madurese have identified Pancasila as their identities.

Relating to this adat mediation, the idea to broaden and strengthen the role and function of this inheemscherechtspraakis considered necessary to overcome all problems leading to carok. Cooperation, synergy, and commitment of local elites (klebun, Kiai, Babibkamtibmas and later) are strategic and pivotal to avoid carok and retaliation to carok in the case of harassment of a man's pride, wife, religion, land, and water disputes that results in shame. Although for the time being, the case of harassment of wife seems to be very difficult to solve, but it is possible that in the future, the case will be solved.

This adat-based solution to social problems is in line with the restorative justice concept. This is in line with Van Camp \&Wemmers Opinion that stated the conception of the value in restorative justice is about healing and recognition of the involved parties, such as victim, offender, and community [8]. This study proposes the presence of the informal justice institution and named as the LMA. The LMA belongs to the IJS, and it is aimed to view crime as more than merely breaking the law, but also it causes harm to people, relationships, and the community. Through the adat-based deliberation method, a just response must be addressed to prevent those harms as well as the wrongdoings. All parties are invited to meet to discuss those harms and how to bring about a resolution. This case in line with Molewijk et al., the opinion which stated that the relatively simple structure of the moral case deliberation methods helps to structure the often tricky and complicated moral cases [11].

In the case of carok, the LMA may be run by local elites (klebun, Kiai, Babinkamtibmas, later) and other respected community members. Apparently, LMA is informal in the sense that it does not apply the existing state methods of conflict resolution. Nevertheless, they might be obliged to adhere to the existing state laws. According to some participants, most peasants and villagers prefer to solve their social problems through this LMA rather than using the state criminal justice systems.

Some participants also stated that rural populations would get better access to the LMA than to the state judiciary systems. They give some reasons such as the procedure takes place on the site, and it will cost less, and it is less prone to corruption. Moreover, it is run 
by trusted people who speak the same language as they do. Besides, decisions are taken based on rules known to all community members. These informal courts typically aim at restoring social peace and order, and they are mostly consent and justice-oriented. Unfortunately, this potential social problem-solving method has not yet been fully utilized in the Madurese social systems.

This indigenous informal court plays a central role in the resolution of disputes, especially those related to behaviors and actions leading to carok. Unfortunately, its relationship to the state justice institutions is problematic. Nonetheless, it is perceived as a legitimate institution by the indigenous people. Therefore, its positive potential can only be effectively practiced if it is connected to the state justice institutions. Moreeffortsonstrengtheningandreformingthe LMAandlinkingthemtostate justice institutions are needed. This is very important to ensure that basic human rights standards are met.

AlthoughtheLMAdoes do not meet there requirement soft heruleo flaw but - in many cases - they can satisfy the rule of law functions [9]. They can play a pivotal role in establishing and maintaining rule-governed behavior among the local populations. They might compliment- and often even substitute - the existing state justice systems for specific tribal conflict resolution like carok.

In the case of carok, the LMA is likely enabledtobringtherestorationofthesocialpeace, andeventoprovidebetter legal certainty. The inclusion of the LMA will lead to a more comprehensive approach toward building the rule of law. To ensureanenoughstandardof human rightsprotectionandfairtrial in conflictresolutionslikecarok, somekindofmonitoringmaybe advisably required. In the long run, there searchershopethatthis LMA shallincreasetheideaof 'access to justice', but not create the opinion of 'poorjusticeforthepoorpeople.' Unfortunately, in Indonesia, visible reformations should not be expected to happen in the years to come.

\section{Conclusion}

The study concluded that (1) Carok is chosen because it is a social norm gaining social supports. In the Madurese tribe, maintaining a man's honor as the most valuable asset in life is a moral commitment that has to be done as his ancestors had practiced it since long ago. (2) Using carok as a final solution to solve problems arise three opinions: (i) Participants who disagree to carok because it just makes society unsafe, disharmonized and anxious with the possible carokretaliation; (ii) Participants who agree fully to carok, since it is regarded as a means to achieve a cultural and substantive justice; (iii) Participants who agree to carok only in the case of harassment of wife. For the case of harassment of a man's honor, religion, land, and water disputes are adequately brought to the informal justice systems. (iv) There is a hope to have powerful generations, and there are crucial roles shared by the local elites such as Kiai, klebun, babinkamtibmasand later in the area of carok (3) The construction of the Madurese legal culture is achieved by (i) encouraging active roles of parents, Kiai, and government which are relevant to the socio-cultural concept of the Madurese's absolute loyalty to Bapa' babhu' ghururato (father/mother, Kiai, and government) ; (ii) influencing people's views that vigilante justice is harmful; (iii) building legal awareness and actively functioning the LMA to overcome the problem of carok and other social problems.

\section{References}


[1] S. S. Silbey, "Legal Culture, and Legal Consciousness. "International Encyclopedia of the Social \& Behavioral Sciences, p. 726-733. 2015,

[2] L. Hong, and Z. Yuxuan, "Building a community of shared future for humankind an ethnological perspective." International Journal of Anthropology and Ethnology2:7, p. 1-8. 2018.

[3] B. De Sousa Santos, "From Customary Law to Popular Justice." Journal of African Law, 28(1-2), p. 90. 1984.

[4] A. Swidler, "Culture in Action: Symbols and Strategies." American Sociological Review, 51(2), p. 273. 1986.

[5] J. T. Heinen, and R. J. Shrivastava, "An analysis of conservation attitudes and awareness around Kaziranga National Park, Assam, India: implications for conservation and development." Population \& Environment, Vol. 30 p. 261-274. 2009.

[6] H.-B., Chia, J. E., Lee-Partridge, \& C.-L. Chong, "Traditional mediation practices: Are we throwing the baby out with the bathwater?"Conflict Resolution Quarterly, 21(4), 2004. p. 451-462.

[7] T. Blass, "The Milgram Paradigm After 35 Years: Some Things We Now Know About Obedience to Authority". Journal of Applied Social Psychology, Vol. 29(5), p. 955-978. 1999.

[8] T. Van Camp, \& J., Wemmers, "Victim satisfaction with restorative justice: More than simply procedural justice." International Review of Victimology, Vol. 19(2), p. 117-143, 2013.

[9] B. Z. Tamahaha, "The Rule of Law and Legal Pluralism in Development.".Hague Journal on the Rule of Law, Vol. 3(1), p. 1-17. 2011

[10] K., Beckett, \& B. Western, "Governing Social Marginality." Punishment \& Society, 3(1), p. 43-59. 2001.

[11] A. C., Molewijk, T., Abma, M., Stolper, \& G. Widdershoven, "Teaching ethics in the clinic. The theory and practice of moral case deliberation."Journal of Medical Ethics, 34(2),2008 p.120-124.

[12] J. A., Conti, \& M. O'Neil, "Studying power: qualitative methods and the global elite." Qualitative Research, 7(1), p. 63-82. 2007 